\title{
Siverek Bölgesinde Yetişen Kenger (Gundelia tournefortii) bitkisinin Ağır Metal, Fenolikasit ve Antioksidan İçeriklerinin Araştırılması
}

\author{
Beşir DAĞ $\breve{G}^{*}$ \\ Batman Üniversitesi, Fen-Edebiyat Fakültesi Kimya Bölümü,72100, Batman, Türkiye \\ (ORCID: 0000-0008-5208-3552)
}

\begin{abstract}
Öz
Bu çalışmada Kenger (Gundelia tournefortii) bitkisinin, ağır metal, fenolik asit ve antioksidan içerikleri araştırıldı. Bitkinin hem kök hem de dikenli kısımlarından olmak üzere toplam 10 örnek alınıp öncelikle, kimyasal yaş yakma işlemi ile çözelti haline getirilip ağır metal [(Arsenik (As), Çinko (Zn), Kadmiyum (Cd), Kobalt (Co), Krom (Cr) Kurşun $(\mathrm{Pb})$, Mangan $(\mathrm{Mn})$, Nikel (Ni) ve Selenyum (Se)] derişimleri İndüktif Eşleşmiş Plazma-Optik Emisyon Spektrometre (ICP-OES) cihazı ile tespit edilerek, literatür verileri ile karşılaştıııldı. Ayrıca, kenger örneklerinin fenolik bileşik içerikleri Sıvı Kromatografisi- Kütle Spektrometresi (LC-MS/MS) cihazı ile kantitatif olarak tayini neticesinde 38 fenolik bileşikten, 28 tanesinin tespit edilebilir seviyenin altında olduğu, geriye kalan ve tespit edilebilir düzeyde olan 10 fenolik bileşik içesinde kuinik asit $\left(4.572 \mathrm{mg} . \mathrm{L}^{-1}-21.28 \mathrm{mg} . \mathrm{L}^{-1}\right)$ ve gallik asit, $(0.284$ $\mathrm{mg} . \mathrm{L}^{-1}-2.182 \mathrm{mg} . \mathrm{L}^{-1}$ ) değerlerinin yüksek, diğer fenolik bileşiklerin ise oldukça düşük seviyelerde olduğu tespit edilmiştir. Sentetik antioksidanlar (BHA, BHT ve Trolox) kullanılarak, $\mathrm{ABTS}^{+}$(Serbest Radikal Giderme), DPPH (Söndürücü Radikal Giderme) ve İndirgeme Güç Yöntemleri kullanılarak bileşiklerin antioksidan aktiviteleri UV spektrofotometre cihazıyla tespit edilerek değerlendirildi. $\mathrm{ABTS}^{+}$radikal giderme sonuçlarına baktığımızda örneklerin metanol ekstraktlarının standartlara kıyasla etkili bir $\mathrm{ABTS}^{+}$radikal katyon giderme aktivitesi göstermediği, metanol ekstraktlarının standartlarla kıyaslandığında, daha düşük seviyede DPPH radikal giderme aktivitesi gösterdiği, ayrıca, kenger örneklerinin metanol ekstraklarının indirgeme gücü aktivitelerinin standartlara göre oldukça düşük seviyede olduğu tespit edilmiştir.
\end{abstract}

Anahtar Kelimeler: Ağır metaller, antioksidan, kenger (Gundelia tournefortii), fenolik bileşikler,

\section{Investigation of Heavy Metal, Phenolic acid and Antioxidant Content of Kenger (Gundelia tournefortii) Samples Growing in Siverek Region}

\begin{abstract}
In this study, heavy metal, phenolic acid and antioxidant contents of Kenger (Gundelia tournefortii) plant were investigated. A total of 10 samples, both root and thorny parts of the plant, are taken and firstly, they are dissolved by chemical wet burning process and heavy metal [(Arsenic (As), Zinc (Zn), Cadmium (Cd), Cobalt (Co), Chromium (Cr) Lead (Pb), Manganese (Mn), Nickel (Ni) and Selenium (Se)] concentrations were determined by Inductively Coupled Plasma-Optical Emission Spectrometer (ICP-OES) device and compared with literature data. Quinic acid (4.572 mg. L $\left.\mathrm{L}^{-1}-21.28 \mathrm{mg} . \mathrm{L}^{-1}\right)$ and gallic acid $\left(0.284 \mathrm{mg} . \mathrm{L}^{-1}-2.182 \mathrm{mg} . \mathrm{L}^{-1}\right)$ values were found to be high, while other phenolic compounds were found to be at very low levels. Synthetic antioxidants (BHA, BHT and Trolox), using $\mathrm{ABTS}^{+}$(Free Ra The antioxidant activities of the compounds were determined and evaluated with a UV spectrophotometer device using DPPH (Extinguishing Radical Removal) and Reduction Power Methods. When we look at the $\mathrm{ABTS}^{+}$radical scavenging results, it was determined that the methanol extracts of the samples did not show an effective $\mathrm{ABTS}^{+}$radical cation scavenging activity compared to the standards, the methanol extracts showed a lower level of DPPH radical scavenging activity compared to the standards, and the reducing power activities of the methanol extracts of the Kenger samples were quite low compared to the standards.
\end{abstract}

Keywords: Heavy metals, antioxidant, kenger (Gundelia tournefortii), phenolic compounds,

*Sorumlu yazar: besir.dag@hotmail.com

Geliş Tarihi: 12.04.2021, Kabul Tarihi: 05.08.2021 


\section{Giriş}

Kenger (Gundelia tournefortii), Dünyanın belli bazı bölgelerinde özellikle de Ortadoğu coğrafyasında, yaygın biçimde ılıman iklim kuşağında yetişen bir bitki türü olduğu bilimsel olarak tespit edilmiştir. Asteraceae familyasından olduğu bilinen kenger (Gundelia tournefortii) bitkisi yaygın biçimde Asya kıtası olmak üzere özellikle de, Azerbaycan, Kıbrıs, İran, İsrail, Mısır, Ürdün ve Türkmenistan gibi 1lıman iklim biçimine sahip ülkelerde yetiştiği bildirilmiştir [1]. Türkiye'nin iklim olarak genellikle 1lıman iklim kuşağında yer alan coğrafi bir bölgede bulunması, onu bitki çeşitliliği açısından oldukça zengin bir kaynağa sahip kılarak birçok aromatik bitkinin yetiştirilmesinde öncü bir konuma taşımanın yanısıra, 3000'i endemik olmak üzere, 12.000 civarında bitki çeşidine sahip olmasıyla da bu alanda lider ülkeler sınıfına yükselttiği yapılan bilimsel araştırmalarla kanıtlanmıştır [2]. Kenger, başta Doğu Anadolu Bölgesi olmak üzere, İç Anadolu ve Güneydoğu Anadolu bölgesinde hatta benzer iklim kuşağına sahip bir çok konum ve farklı rakımlarda yetiştiği de tespit edilmiştir [3]. Genetik yapısı bakımından tek tohumlu olan kenger bitkisi bölgelere göre farklılıklar göstermekle birlikte genellikle 20-40 cm yüksekliğinde uzun ömürlü, otsu ve dikenli yapıda, tüylü veya tüysüz yaprakları loplu biçimde olup, bu lopların uç kısımları dikenli yapıya sahip bir bitki türüdür. Türkiye'de kenger bitkisi, kenger sakızı, sakız otu, tatlı kenger, çadır dikeni ve kanak olmak üzere farklı isimlerle anıldığı ve isimlerinde bölgelere göre farklılıklar gösterdiği gibi, tüketim alışkanlıklarını da etkilediği bilinmektedir. Doğu Anadolu bölgesinde kengerin enginara benzeyen baş kısmı ve sapları sebze olarak tüketilirken, Akdeniz ve iç bölgelerde kavrululup, taş dibekle dövüldükten sonra, elekten geçirilerek, kenger kahvesi şeklinde tüketilmektedir [4-6]. Bunun yansıra, kenger stabilizatör olarak dondurma imalatında kullanılabildiği gibi [7], kök kısımlarından elde edilen yoğun kıvamdaki kenger sütünden de sakız elde edilerek halk arasında birçok faydaları olduğu bilinip şifa niyetine çiğnenerek tüketilmektedir.Kenger bitkisi $(G$. tournefortii) uzun yıllar boyunca birçok toplumlar tarafindan geleneksel yâda alternatif tıpta da kullanıldığı, sap kısımlarının özellikle karaciğer koruyucu ve kan temizleyici özelliklere sahip olduğu bilinmektedir.Ayrıca, şeker hastalığı tedavisi, ağrı kesici, kramp çözücü, hazımsızlığı giderici, sinirleri güçlendirip rahatlatıcı, ve migreni tedavi edici gibi birçok faydalı özelliklerinin yanısıra [3, 8-11], antiinflamatuar, anti-parazit, antibakteriyel, hipoglisemik ve hepatoprotektif etkilerinin de olduğu belirtilmiştir $[1,6]$.

Kenger bitkisinin (G. tournefortii) kimyasal yapısı, bilhassa da içermiş olduğu fenolik bileşikler sayesinde birçok patolojik vakanın engellenmesinde önemli dercede rol oynamış olmakla birlikte insan sağlığı üzerinde bir çok pozitif etkileri olduğu tespit edilmiştir. Fenolik bileşikler kimyasal yapıları bakımından bir ya da birden çok aromatik halkaya sahip bileşik gruplarıdır. Kimyasal içeriği ve farklı şekillerde yer alan hidroksil gruplarına bağlı olarak basit fenolikler, fenolik asitler, asetofenonlar, aldehitler ve fenil asetikler, kumarinler, sinamik asitler, biflanoniller, flavonidler, ksantone, benzofenon, stilbenler, benzokinon, antrakinon, naftakinonlar, betasiyaninler, lignanlar, lignin ve tanenler biçiminde sinıflandırılırlar [12]. Bitkilerde sekonder metabolizmanın ürünleri olarak ortaya çıkan fenolik bileşiklerin, parazit ve patojenlere karşı kendilerini savunmalarının, bitkilerin üreme ve büyüme gibi temel gelişim fonksiyonlarına olumlu katkı sağladıkları gibi, bitkilerin tatlarına ve renklerine de aynı şekilde olumlu katkılar sağladıkları belirtilmiştir [13]. Fenolik bileşiklerin bileşenlerinin çok önemli bir kısmı antioksidan özellik kapasitesine sahip oldukları gibi antioksidan güç sebebiyle birçok hastalık üzerinde düzeltici ve önleyici etkilerinin olduğu da tespit edilmiştir [14]. Antioksidanlar daha seyreltik derişimlerdeki, serbest radikaller ile tepkimeye girip, onların okside olmasına engel olan bileşikler olarak tanımlanmışlardır. Antioksidan kapasitesi bakımından zengin olan besin, gıda yâda bitkilerin birçok hastalıklara karşı, koruyucu etkiye sahip oldukları ve bunların tüketiminin yâda kullanımının özellikle kanser hastalıkları, kalp hastalıkları ve hipertansiyon hastalıklarını tedavi ettiği, hatta felç riskini önemli ölçüde azalttı̆̆ tespit edilmiştir [15]. Besin ve bitkilerin antioksidan kapasiteleri önemli olmakla birlikte bunların biyoalınabilir seviyede olması, o bileşenden yararlanmayı daha da önemli hale getirmiş olup, son zamanlarda bu konu üzerine çok sayıda makale yayınlanmıştır [16-21]. Biyoyararlılık, besinlerde bulunan bileşenlerin vücudumuz tarafindan sindirilip vücut fonksiyonlarına dahil olması için kullanılan yada depolanan miktarı, yani vücudun, sahip olduğu gıdalarda bulunan bileşimlerin kullanılma yada tüketilme oranı olarak tanımlanmıştır. Ülkemizde yetiştirilen ve sıklıkla tüketilen kenger ( $G$. tournefortii) bitkisinin hem dikenli hem de yenilebilir kısmının ağır metal derişimleri kimyasal yaş yakma işlemi ile çözelti haline getirilip İndüktif Eşleşmiş Plazma-Optik Emisyon Spektrometresi (ICP-OES) cihazı ile ölçülerek, bulunan değerler literatür verileri ile 
karşılaştırılması, ayrıca fenolik asit içeriklerini tespit etmek için iki farklı özütleme metodu kullanılarak toplam fenolik bileşik içerikleri ve antioksidan kapasitesinin belirlenmesi hedeflenmiştir.

\section{Materyal ve Metot}

\subsection{Kenger Örneklerinin A ğır Metal Analizleri}

Kenger örnekleri Siverek-Diyarbakır karayolunun 16. kilometresinde yolun her iki tarafından toplanıp, naylon poşetlere konup, kilitlenerek etiketlendi. Plastik bir bıçak yardımı ile kenger örneklerinin kök ve dikenli kısımları ayrıldı. Örnekler yenilebilir ve dikenli kısım olmak üzere iki kısma ayrılıp, numaralandırıldıktan sonra $55{ }^{\circ} \mathrm{C}$ de ki etüvde 60 saat süreyle kurutuldu [22]. Kuruyan kenger örneklerinin kök ve dikenli kısımları porselen havanda öğütülüp toz haline getirilerek, kapaklı tüplere aktarılıp etiketlendi. Kenger örnekleri yaş yakma metodu ile çözelti haline getirilmek için, porselen krozeler hazırlanarak tartımları alınıp, $500{ }^{\circ} \mathrm{C}$ 'ye ayarlanan kül fırınına yerleştirilerek sabit tartıma gelmesi sağlandı. Örneklerden yaklaşık,1.5 gr katılarak krozelerin tartımları alındı. Her bir örneğin üzerine \% 95 etanol $\left(\mathrm{C}_{2} \mathrm{H}_{5} \mathrm{OH}\right)$ - \% 5 Nitrik asit $\left(\mathrm{HNO}_{3}\right)$ karışımından oluşan çözeltiden 4 ml eklendi. $550{ }^{\circ} \mathrm{C}$ ' sıcaklıkta 6 saat sonunda kül haline gelen kenger örnekleri metal bir maşa kullanılarak etüvden çıkarıldı, üzerlerine $3 \mathrm{~N}, \mathrm{HCl}$ çözeltisinden 4'er ml eklendikten sonra kenger örnekleri ayrı ayrı mavi bant süzgeç kâğıdıyla falkon tüplerine süzülerek saf suyla 15 ml’ye tamamlandı [23].

\subsubsection{ICP-OES cihazının analitik koşulları}

Plazma akışı (15 L.dk $\left.{ }^{-1}\right)$, Nebulizer gaz basıncı ( $\left.0.80 \mathrm{~L}^{\mathrm{d}} \mathrm{dk}^{-1}\right)$, Tekrar okuma süresi (15 saniye), Cihaz stabilizasyon zamanı (30 saniye), Örnek alım gecikmesi (50 saniye), Yıkama süresi (10 saniye), Pompa hızı ( $\sqrt{ })$ Yardımcı gaz akışı $\left(2.25{\mathrm{~L} . \mathrm{dk}^{-1}}^{-1}\right.$.

\subsubsection{Sonuçların hesaplanması}

Costech ECS 4010 Elementel analiz cihazı (analitik koşullar: Akış hızı: $100 \mathrm{ml} . \mathrm{dk}^{-1}$, Dedeksiyonon: TCD: L-3, Dedektör 1: INT 7-1, External Start: Start - Restart, Down, Fırın sıcaklığı: 70 ${ }^{\circ}$ C, GC Kolonu: SS 6×5 mm - 2 m - HayeSep Q 60/80, Metod: Dumas metodu, $\mathrm{O}_{2}$ loop: $5 \mathrm{ml}-100 \mathrm{kPa}$, Otomatik kapama: 15.00 min, Packing: NCHS için standart, Reaksiyon tüpü: $450 \times 18 \mathrm{~mm}$, Sağ firın sicaklığı: off, Sol firın sıcaklığı: $1050{ }^{\circ} \mathrm{C}$, Tanımlı Elementler: $(\mathrm{N}, \mathrm{C}, \mathrm{H}, \mathrm{S})$ analitik koşullara getirilip plazma yakıldı, cihazın stabilizasyonundan sonra analiz başlatılarak, sırasıyla tanık çözelti, kalibrasyon standart çözeltileri, kontrol standart çözeltileri ile numune çözeltileri okundu. Her bir element ve o element için seçilmiş her bir dalga boyu için en az dört noktalı bir kalibrasyon eğrisi oluşturuldu. Kenger örneklerindeki element miktarları aşağıdaki formül kullanılarak cihaz tarafindan hesaplandı. Sonuçlar, mg.kg-1 olarak hesapland.

$M=(n-t) x V / m$ n: Numune çözeltisinin element derişimi $\left(\mu \mathrm{g} \cdot \mathrm{ml}^{-1}\right) \mathrm{t}$ : Tanık çözeltinin element konsantrasyonu $\left(\mu \mathrm{g} \cdot \mathrm{ml}^{-1}\right), \mathrm{V}$ : Numune çözeltisinin hacimi $(\mathrm{ml}), \mathrm{m}$ : Numune tartım miktarı $(\mathrm{g}), \mathrm{M}$ : Numunedeki element miktarı $\left(\mu \mathrm{g} \cdot \mathrm{g}^{-1}\right)$.

\subsection{Kenger Örneklerinin Fenolik Asit Analizleri}

$250 \mathrm{ml}$ 'lik cam balon jojelerin içine iyice kurutulan kenger örnekleri $10 \pm 0.5 \mathrm{~g}$ duyarlılıkta tartılarak kondu. Çözücü olarak polar özellik taşıyan etanol kullanıldı. Soxhlet ekstraktörü kullanılarak geri damıtma hızı dakikada en az üç damla olacak şekilde 8-10 saat ekstrakte edildi. Rotary Evaporatör yardımıyla düşük basınç altında, çözücü iyice buharlaştıııldı [24]. Fenolik bileşiklerin kalitatif ve kantitatif olarak tayini LC-MS/MS cihazıyla gerçekleştirildi. LC-MS/MS analizlerinde bazı Achillea L. türlerinin LC-MS/MS ile metabolik profillerinin çıkarılmasında kullanılan metot modifiye edilerek uygulandı [25]. Ekstraksiyon sonucunda elde edilen ham ekstreler metanol da çözünerek $1000 \mathrm{mg} \cdot \mathrm{kg}^{-1}$ derişimde 1.5 ml'lik çözeltileri hazırlanıp $0.22 \mu \mathrm{m}$ filtreden geçirilip HPLC viallerine aktarıldı. 


\subsubsection{Fenolik bileşiklerin tayininde kullanılan alet, cihaz ve kimyasallar}

Protokateşuik asit, ferulik asit, klorojenik asit, rozmarinik asit, sinnamik asit, sinapinik asit, sirinjik asit, pirokatekol, p-kumarik asit, o-kumarik asit, gallik asit, 4-hidroksi benzoik asit, kafeik asit, vanilik asit, salisilik asit, hesperidin, apigetrin, likiritigenin, izokersitrin, hesperetin, roifolin, nikotiflorin, fisetin, naringenin, rutin, kersetin, kamferol, mirisetin, kersitrin, luteolin, apigenin, krisin, malikasit, kinik asit, fumarik asit, kumarin, vanilin, formik asit, amonyum format, ultra saf su ve metanol kullanıldı.Hassas terazi (Scaltec SBA31), Jeio-Tech ultrasonik banyo (Kore), LC-MS/MS (Shimadzu LCMS 8040 model), Otomatik pipetler (10-100 $\mu \mathrm{L}, 100-1000 \mu \mathrm{L}, 500-5000 \mu \mathrm{L})$ (Eppendorf, Almanya), pH-metre (Thermo, Amerika Birleşik Devletleri), Rotary evaporator (Büchi, İsviçre), Ultra saf su cihazı (Sartorious, Arium Pro, Almanya), Vortex (LMS Co. LTD, Japonya).

\subsubsection{LC-MS/MS cihazı kromatografik şartları}

DL sicaklığı: $250{ }^{\circ} \mathrm{C}$, Isı blok sicaklığı: $400{ }^{\circ} \mathrm{C}$, Ara yüz sıcaklı̆̆g: $350{ }^{\circ} \mathrm{C}$, kuru gaz $\left(\mathrm{N}_{2}\right)$ sicaklığı: 15 L.dk ${ }^{-1}$, nebulizator gaz $\left(\mathrm{N}_{2}\right)$ akışı: 3 L.dk ${ }^{-1}$, Kromatografik ayrım, Inertsil ODS-4 model $\mathrm{C}_{18}(100$ $\mathrm{mm} \times 2.1 \mathrm{~mm}, 2 \mu \mathrm{m}$ ) kolonda gerçekleştirilmiştir. Analiz aşamasında kolon firının sıcaklığ $35^{\circ} \mathrm{C}$ 'ye ayarlandı. Elüsyon gradiyentinde hareketli faz A şişesi için ultra saf su ve hareketli faz B şişesi için metanol kullanıldı. Kromatografik ayrımı ve iyonlaştırmayı kolaylaştırmak için su fazına $10 \mathrm{mM}$ amonyum format $\left(\mathrm{HCO}_{2} \mathrm{NH}_{4}\right)$ ve $\% 0.1$ formik asit $\left(\mathrm{CH}_{2} \mathrm{O}_{2}\right)$ eklendi. Örneklerin en uygun ayrımının gerçekleşmesi için uygulanan gradient program $5-20 \%$ B (1-10 dk), 20\% B (9-22 dk), 21-50\% B (23$35 \mathrm{dk}), 95 \%$ B (35-40), 5\% B (42-50 dk) şeklinde ayarlandı. Hareketli faz akış hızı 0,25 mL.dk ${ }^{-1}$ ve enjeksiyon hacmi $4 \mu \mathrm{L}$ olarak belirlendi.

\subsubsection{Toplam fenolik bileşik tayini}

Ham bitki ekstraktının total fenolik bileşik tayini Folin-Ciocalteu reaktifi ile yapıldı. Bitki ekstraktı (0.5 $\left.\mathrm{mL}, 1 \mathrm{mg} . \mathrm{mL}^{-1}\right)$ üzerine 10 kat seyreltilmiş Folin-Ciocalteu reaktifi $(2.5 \mathrm{~mL})$ ve $\mathrm{Na}_{2} \mathrm{CO}_{3}\left(2 \mathrm{~mL}, 75 \mathrm{mg} . \mathrm{L}^{-}\right.$ $\left.{ }^{1}\right)$ ilave edildi. $\mathrm{Bu}$ karışım vortekslendikten sonra $50^{\circ} \mathrm{C}$ 'de 5 dakika inkübe edildi. Numuneler oda sıcaklığına getirildikten sonra $760 \mathrm{~nm}$ 'deki absorbansları spektrofotometrede kaydedildi. Standart olarak kullanılan gallik asitin farklı derişimleriyle elde edilen kalibrasyon eğrisi oluşturuldu. Sonuçlar mg. $\mathrm{L}^{-1}$ gallik aside eşdeğer fenolik madde \pm standart sapma olarak hesaplandı.

\subsection{Kenger Örneklerinin Antioksidan Aktiviteleri ve Kimyasallar}

ABTS (2,2'-azino-bis (3-etilbenzotiyazolin-6-sülfonikasit, diamonyumtuzu), BHA, (Butillenmiş hidroksi anisol), BHT (Butillenmiş hidroksi tolüen), DPPH (1,1-difenil-2-pikrilhidrazil), Etanol, $\mathrm{FeCl}_{3}$, Gallik asit, Potasyum dihidrojen fosfat $\left.\left(\mathrm{KH}_{2} \mathrm{PO}\right)_{4}\right)$, Potasyum ferrisiyanür $\left[\mathrm{K}_{3} \mathrm{Fe}(\mathrm{CN})_{6}\right]$, Potasyum hidroksit $(\mathrm{KOH})$, Potasyum persülfat $\left(\mathrm{K}_{2} \mathrm{~S}_{2} \mathrm{O}_{8}\right)$, Sodyum karbonat $\left(\mathrm{Na}_{2} \mathrm{CO}_{3}\right)$, Trolox kullanıldı. Kenger örneklerinin antioksidan aktiviteleri UV spektrofotometre cihazı ile ölçüldü.

\subsubsection{ABTS $^{++}$radikal giderme tayini}

Serbest radikal $\left(\mathrm{ABTS}^{-+}\right)$giderme aktivitesi Re'nin önerdiği metoda göre yapıldı [26]. Serbest radikal $\left(\mathrm{ABTS}^{++}\right.$) giderme aktivitesi için $0,1 \mathrm{M} \mathrm{pH}$ ' 7.4 olan $\mathbf{P O}_{4}{ }^{3-}$ tamponu, $2 \mathrm{mM}^{\prime} \mathrm{l}_{\mathrm{k}} \mathrm{ABTS}{ }^{++}$ve $2.45 \mathrm{mM}^{\prime} \mathrm{l}_{1 \mathrm{k}}$ $\mathrm{K}_{2} \mathrm{~S}_{2} \mathrm{O}_{8}$ çözeltisi hazırlandı. ABTS ${ }^{+}$ve $\mathrm{K}_{2} \mathrm{~S}_{2} \mathrm{O}_{8}$ çözeltileri (1:2) $\mathrm{ABTS}^{++}-\mathrm{K}_{2} \mathrm{~S}_{2} \mathrm{O}_{8}$ olacak şekilde karıştırıldı ve 6 saat boyunca karanlıkta inkübe edildi. Farklı derişimlerde (10-20-40 mL) örnek ve standart çözeltileri alındı ve üzerlerine $1 \mathrm{ml} \mathrm{ABTS}^{+}-\mathrm{K}_{2} \mathrm{~S}_{2} \mathrm{O}_{8}$ çözeltisi toplam hacim $4 \mathrm{ml}$ olacak şekilde ilave edildi. Karışım şiddetli şekilde vortekslenerek 30 dakika inkübe edildi. Spektrofotometrik ölçüm oda şartlarında, 734 nm'de yapıldı. Ölçümler üç tekrarlı yapılarak ortalamaları alındı. Örneklerin ve standartın \% katyon serbest radikal giderme aktivitesi aşağıdaki formüle göre hesaplandı [27].

$$
\begin{aligned}
& \% \text { Aktivite }=\frac{\mathrm{Abs}_{\text {kontrol }}-\mathrm{Abs}_{\text {numune }}}{\mathrm{Abs}_{\text {kontrol }}} \times 100 \\
& \mathrm{Abs}_{\text {kontrol }}=\mathrm{PO}_{4}^{3-} \text { tamponu }+\mathrm{ABTS}^{++}-\mathrm{K}_{2} \mathrm{~S}_{2} \mathrm{O}_{8} \text { çözeltisinin absorbans1, }
\end{aligned}
$$




$$
\begin{aligned}
& \mathrm{Abs}_{\text {numune }}=\frac{\mathrm{PO}_{4}^{3-} \text { tamponu }+\mathrm{ABTS}^{+}-\mathrm{K}_{2} \mathrm{~S}_{2} \mathrm{O}_{8} \text { çözeltisi }+ \text { ekstrakt }}{\text { standart absorbans1 }} \\
& \mathrm{Abs}_{\text {kör }}=\mathrm{PO}_{4}^{3-} \text { tamponu }, \text { Standart }=\text { Trolox }
\end{aligned}
$$
hesapland1.

Sonuçlar, derişime karşı \% aktivite grafiği çizildi. Eğim denkleminden yararlanılarak $\mathrm{IC}_{50}$

\subsubsection{DPPH’ serbest radikal giderme tayini}

Serbest radikal (DPPH') giderme aktivitesi Liyana-Pathirana'nın özetlediği metoda göre yapıldı (Liyana-Pathirana ve Shaihidi,2005). DPPH (2,2-difenil-1-pikril hidrazil) 0,135 mM'lik etanol çözeltisinin $1 \mathrm{~mL}$ 'si üzerine farklı derişimlerde (40-80-160 mg. $\left.\mathrm{mL}^{-1}\right)$ numune çözeltisi ilave edildi. Son hacim etanol ile $4 \mathrm{~mL}$ 'ye tamamlandı. Karışım şiddetli şekilde vortekslenerek oda sıcaklığında ve karanlıkta inkübe edildi. Spektrofotometrik ölçüm oda şartlarında, $517 \mathrm{~nm}$ 'de yapıldı. Numunelerin \% serbest radikal giderme aktivitesi aşağıdaki formüle göre hesaplandı.

$$
\begin{array}{ll}
\% \mathrm{SRG}=\frac{\mathrm{Abs}_{\text {kontrol }}-\mathrm{Abs}_{\text {numune }}}{\mathrm{Abs}_{\text {kontrol }}} \times 100 & \mathrm{ABS}_{\text {kontrol }}=\text { etanol }+\mathrm{DPPH} \text { çözeltisinin absorbansı, } \\
\mathrm{Abs}_{\text {numune }}=\frac{\text { etanol }+\mathrm{DPPH}+\text { ekstrakt }}{\text { standart absorbans1 }} & \text { Sonuçlar, \% serbest radikal giderme } \pm \text { standart sapma }
\end{array}
$$

\subsection{3. İndirgeme gücü}

İzole edilecek moleküllerin ve ham ekstraktın indirgeme gücü Oyaizu metoduna göre değerlendirildi [28]. Standart ve numunelerin etanol içindeki farklı derişimlerine $\left(40,80\right.$ ve $120 \mathrm{mg}$. $\left.\mathrm{mL}^{-1}\right)$ fosfat tamponu $(2.5 \mathrm{~mL}, 0.2 \mathrm{M}, \mathrm{pH} 6.6)$ ve potasyum ferrisiyanür $\left[\mathrm{K}_{3} \mathrm{Fe}(\mathrm{CN})_{6}\right](2.5 \mathrm{~mL}, \% 1)$ ilave edildi. $\mathrm{Bu}$ karışım $50^{\circ} \mathrm{C}^{\prime}$ de 20 dakika inkübe edildi. İnkübasyondan sonra, bu karışıma TCA ( $\left.2.5 \mathrm{~mL}, \% 10\right)$ ilave edildi ve sonra 10 dakika 3000 rpm'de santrifüjlendi. Karışımdan $2.5 \mathrm{~mL}$ alınarak destile su $(2.5 \mathrm{~mL})$ ve $\mathrm{FeCl}_{3}(0.5 \mathrm{~mL}, \%$ 0.1) ilave edilerek son karışımın absorbansları $700 \mathrm{~nm}$ 'de ölçüldü. Yüksek absorbans değeri yüksek indirgeme gücü olarak değerlendirildi.

\section{4. İstatistiksel Analiz}

Antioksidan aktivite sonuçlarından elde edilen veriler, 3 paralel ölçümün ortalaması ve standart sapması olarak verilmiştir. Sonuçlar t-testine göre \% 95 güven sınırları içinde bulundu. Anlamlılık sınırı olarak $\mathrm{p}<0.05$ kabul edildi. Eğim ve kesişme korelasyon katsayısının değerlendirilmesi sonucunda en küçük kareler yöntemi kullanılarak doğrusal regresyon analizi yapılmıştır.

\begin{tabular}{|c|c|c|c|c|c|c|c|c|c|}
\hline \multirow{2}{*}{$\begin{array}{l}\text { Kenger } \\
\text { Örnekleri }\end{array}$} & \multicolumn{9}{|c|}{ Kenger Örnekleri Ağırmetal Derişimleri (mg.L $\left.{ }^{-1}\right)$} \\
\hline & As & $\mathbf{Z n}$ & Cd & Co & $\mathbf{P b}$ & $\mathrm{Cr}$ & Mn & $\mathbf{N i}$ & Se \\
\hline $1 Y$ & 0.23 & 1271.30 & 1.25 & 3.56 & 7.26 & 29.55 & 293.92 & 79.09 & 0.98 \\
\hline $2 Y$ & 0.39 & 1262.54 & 1.55 & 3.81 & 5.84 & 29.01 & 319.33 & 90.88 & 0.57 \\
\hline $3 \mathrm{YY}$ & 0.39 & 1313.24 & 3.54 & 7.14 & 19.42 & 10.86 & 319.86 & $\begin{array}{l}64.44 \\
\end{array}$ & 1.00 \\
\hline $4 Y$ & 0.29 & 1342.88 & 2.92 & 33.37 & 16.48 & 23.68 & 351.69 & 59.41 & 1.04 \\
\hline $5 Y$ & 0.31 & 1521.17 & 3.63 & 74.01 & 14.57 & 14.99 & 373.05 & 60.01 & 1.22 \\
\hline $\begin{array}{l}\text { Ortalama } \\
\pm \text { SS }\end{array}$ & $\begin{array}{l}0.32 \pm 0.0 \\
69\end{array}$ & $\begin{array}{l}1342.23 \pm 105 \text {. } \\
169\end{array}$ & $\begin{array}{l}2.58 \pm 1.1 \\
15\end{array}$ & $\begin{array}{l}24.38 \pm 30 \\
405\end{array}$ & $\begin{array}{l}12.71 \pm 5 \\
908\end{array}$ & $\begin{array}{l}21.62 \pm 8 \\
389\end{array}$ & $\begin{array}{l}331.57 \pm 30 \\
943\end{array}$ & $\begin{array}{l}70.77 \pm 13 \\
771\end{array}$ & $\begin{array}{l}0.96 \pm 0.2 \\
39\end{array}$ \\
\hline
\end{tabular}

\section{Bulgular ve Tartışma}

\subsection{Kenger örneklerinin ağır metal derişimleri}

Tablo 1. Yenilebilir kenger örneklerinin ağır metal derişimleri (mg. $\left.\mathrm{L}^{-1}\right)$ 
Tablo 2. Dikenli kenger örneklerinin ağır metal derişimleri (mg. $\left.\mathrm{L}^{-1}\right)$

\begin{tabular}{|c|c|c|c|c|c|c|c|c|c|}
\hline \multirow{2}{*}{$\begin{array}{l}\text { Kenger } \\
\text { Örnekleri }\end{array}$} & \multicolumn{9}{|c|}{ Kenger Örnekleri Ağırmetal Derişimleri (mg.L $\left.\mathbf{L}^{-1}\right)$} \\
\hline & As & $\mathbf{Z n}$ & Cd & Co & $\mathbf{P b}$ & $\mathrm{Cr}$ & Mn & $\mathbf{N i}$ & Se \\
\hline 1D & 0.80 & 1258.60 & 1.51 & 25.05 & 18.24 & 20.82 & 658.40 & 85.93 & 1.31 \\
\hline 2D & 0.78 & 1222.58 & 4.74 & 10.26 & 10.39 & 22.01 & 579.65 & 71.91 & 1.66 \\
\hline 3D & 0.90 & 1232.65 & 5.96 & 14.51 & 16.82 & 44.01 & 578.88 & 72.83 & 1.26 \\
\hline 4D & 0.76 & 1308.47 & 1.09 & 77.62 & 4.80 & 21.36 & 628.56 & 90.70 & 1.42 \\
\hline 5D & 1.34 & 1350.68 & 17.72 & 53.98 & 33.85 & 27.58 & 780.83 & 67.99 & 1.38 \\
\hline $\begin{array}{l}\text { Ortalama } \\
\pm \text { ss }\end{array}$ & $\begin{array}{l}0.92 \pm 0.2 \\
43\end{array}$ & $\begin{array}{l}1274.6 \pm 53.9 \\
84\end{array}$ & $\begin{array}{l}6.2 \pm 6.7 \\
64\end{array}$ & $\begin{array}{l}36.28 \pm 28 . \\
72\end{array}$ & $\begin{array}{l}16.82 \pm 10 . \\
93\end{array}$ & $\begin{array}{l}27.16 \pm 9.8 \\
04\end{array}$ & $\begin{array}{l}645.26 \pm 82.9 \\
79\end{array}$ & $\begin{array}{l}77.87 \pm 9 . \\
85\end{array}$ & $\begin{array}{l}1.41 \pm 0.1 \\
55\end{array}$ \\
\hline
\end{tabular}

Tablo 3. Topraklarda bulunabilecek ağır metallerin sınır değerleri(mg.kg $\left.{ }^{-1}\right)$ [29].

\begin{tabular}{|l|c|c|}
\hline Ă̆ır Metaller & $\mathrm{pH}<6$ & $\mathrm{pH}>6$ \\
\hline Arsenik(As) & 0,1 & $1^{* *}$ \\
\hline Çinko(Zn) & $150^{* * *}$ & $300^{* *}$ \\
\hline Kadmiyum(Cd) & $1^{* *}$ & $3^{* *}$ \\
\hline Kobalt(Co) & $10-$ & 15 \\
\hline Krom(Cr) & $100^{* *}$ & $100^{* *}$ \\
\hline Kurşun(Pb) & $50^{* *}$ & $300^{* *}$ \\
\hline Mangan(Mn) & $21,4^{* *}$ & 300 \\
\hline Nikel((Ni) & $30^{* *}$ & $75^{* *}$ \\
\hline Selenyum(Se) & $100^{* *}$ & $400^{* *}$ \\
\hline
\end{tabular}

*: pH değeri 7'den büyük ise bakanlık sınır değerleri \%50'ye kadar artırabilir.

**: Yem bitkileri yetiştirilen alanlarda çevre ve insan sağlığına zararlı olmadığı bilimsel çalışmalarla kanıtlanmıştır.

\subsubsection{Kenger örneklerinin ağır metal tayin sonuçları}

Ağır metaller insan, çevre ve canlılar üzerinde çok fazla etkileri olan metallerdir [30]. Bu elementler genellikle topraktan, bitkiye ve meyvelere vesilsile halinde canlı ve insana kadar uzanmaktadır. Bitki ve meyvelerde bulunan ağır metaller hem besleyici hem de toksik özellik taşımaktadırlar [22]. Kenger bitkisinde bulunan hem besleyici hem de toksik etkileri olduğu bilinen dokuz ağır metalin kantitatif tayinleri yapılarak elde edilen derişimleri Tablo 1'de ortalama ve standart sapmaları ile birlikte verilmiştir. Ayrıca ekolojik açıdan önemli ağır metaller ve bunların toprakta kabul edilebilen sınır değerleri ile birlikte $\mathrm{pH}$ değerine bağlı olarak değişkenlik gösteren değerleri de (Tablo 2)'de ayrıntılı biçimde verilmiştir. $\mathrm{Bu}$ çalışma sonucunda kenger bitkisin ağırmetal derişimlerini değerlendirdiğimizde, özellikle çinko (Zn) metalinin derişiminin diğer metallere oranla çok yüksek ve sınır değerinin çok üzerinde olduğu dikkat çekmektedir. Çinko besleyici bir element olmasına rağmen derişiminin bu derece yüksek olması kabul edilebilir bir durum değildir. Bunun yanı sıra Mangan (Mn) elementinin derişiminin birçok örnekte kabul edilebilen sınır değerinin üzerinde seyrettiği gözlemlenmiştir. Ayrıca kadmiyum, kobalt ve nikel gibi elementlerin bazı derişimleri benzer biçimde sınır değerlerini aştığı gözlemlenmiştir [29]. Burada dikkat çeken en önemli nokta ise toksik etkiye sahip Krom (Cr) metalinin derişiminin kabul edilen sınır değerinin oldukça altında olmasıdır.Bir diğer toksik etki gösteren Arsenik (As) metalinin de kabul edilebilen sınır değere yakın olması sevindirici ve nispeten kabul edilebilir bir durumdur.bir diğer toksik element olan kurşunun ise kabul edilelebilir seviyede olması hatta örneklerin karayolları kenarından alınmış olmasına rağmen, derişimlerinin düşük seviyelerde olması toprağın Kurşun $(\mathrm{Pb})$ açısından temiz olduğunu göstermektedir.Elde edilen sonuçları toprak için değerlendirdiğimizde; kenger bitkisi açısından daha pozitif bir düşünceye sahip olabiliriz zira ağır metaller topraktan bitkiye geçerken derişiminde yaklaşık olarak yarı yarıya bir azalma beklenmektedir [22]. Bu çalışma neticesinde, iki önemli husus dikkat çekerek ön plana çıkmıştır. Birincisi besleyici özelliğe sahip olan Çinko (Zn) metalinin derişiminin çok yüksek olmasının yanısıra bir diğer besleyici özelliği olan Selenyumun (Se) derişiminin çok düşük sevide olması, ikincisi ise toksik özellikleri olan, Kurşun $(\mathrm{Pb})$, Kadmiyum $(\mathrm{Cd})$ ve Arsenik (As) elementlerin derişimlerinin düşük seviyelerde olması kenger bitkisinin hem dikenli hem de yenilebilir kısmının toksik seviyelerin çok altında olması, bitkinin tüketilmesinin insan sağlığı açısından hiç bir olumsuz etkisinin bulunmadığının göstergesidir. 


\subsection{Kenger örneklerindeki fenolik bileşik derişimleri}

Tablo 4. Yenilebilir kenger örneklerindeki fenolik bileşiklerin derişimleri (mg. $\left.\mathrm{L}^{-1}\right)$

\begin{tabular}{|l|l|l|l|l|l|l|}
\hline \multirow{2}{*}{ Fenolik Bileşikler } & \multicolumn{5}{|c|}{ Kenger örneklerindeki fenolik bileşiklerin derişimleri } \\
\cline { 2 - 7 } & $\mathbf{1 Y}$ & $\mathbf{2 Y}$ & $\mathbf{3 Y}$ & $\mathbf{4 Y}$ & $\mathbf{5 Y}$ & Ortalama \pm ss \\
\hline Kuinik Asit & 6.372 & 4.572 & 8.876 & 9.321 & 7.382 & $7.3 \pm 1.929$ \\
\hline Galik Asit & 0.846 & 0.284 & 0.858 & 0.621 & 0.321 & $0.59 \pm 0.276$ \\
\hline Protokateşuik & 0.037 & 0.089 & 0.032 & 0.051 & 0.014 & $0.04 \pm 0.028$ \\
\hline Klorojenik Asit & 0.091 & 0.315 & 0.234 & 0.165 & 0.321 & $0.23 \pm 0.099$ \\
\hline Salisilik Asit & 0.041 & 0.017 & 0.033 & 0.021 & 0.03 & $0.03 \pm 0.01$ \\
\hline p-Kumarik Asit & - & - & - & - & - & - \\
\hline Hesperidin & - & 0.013 & 0.011 & - & - & $0.01 \pm 0.001$ \\
\hline Naringenin & - & 0.028 & 0.026 & - & - & $0.03 \pm 0.001$ \\
\hline Kaempferol & - & 0.048 & 0.065 & - & - & $0.06 \pm 0.012$ \\
\hline
\end{tabular}

Tablo 5. Dikenli kenger örneklerindeki fenolik bileşiklerin derişimlerleri (mg. $\left.\mathrm{L}^{-1}\right)$

\begin{tabular}{|l|l|l|l|l|l|l|}
\hline \multirow{2}{*}{ Fenolik Bileşikler } & \multicolumn{5}{|c|}{ Kenger örneklerindeki fenolik bileşiklerin derişimleri } \\
\cline { 2 - 7 } & 1D & 2D & 3D & 4D & 5D & Ortalama \pm ss \\
\hline Kuinik Asit & 19.39 & 16.107 & 23.02 & 21.28 & 18.13 & $19.59 \pm 2.689$ \\
\hline Galik Asit & 2.182 & 1.646 & 1.493 & 1.325 & 2.11 & $1.75 \pm 0.379$ \\
\hline Protokateşuik & 0.034 & 0.027 & 0.024 & 0.029 & 0.039 & $0.03 \pm 0.006$ \\
\hline Klorojenik Asit & 0.214 & 0.186 & 0.144 & 0.223 & 0.254 & $0.2 \pm 0.041$ \\
\hline Salisilik Asit & 0.662 & 0.222 & 0.03 & 0.224 & 0.018 & $0.23 \pm 0.261$ \\
\hline p-Kumarik Asit & 1.075 & 0.895 & - & 0.025 & - & $0.67 \pm 0.562$ \\
\hline Hesperidin & 0.056 & 0.03 & 0.009 & - & - & $0.03 \pm 0.024$ \\
\hline Naringenin & 0.012 & 0.025 & 0.062 & - & - & $0.03 \pm 0.026$ \\
\hline Kaempferol & 0.101 & 0.102 & 0.047 & - & - & $0.08 \pm 0.031$ \\
\hline
\end{tabular}

\subsubsection{Kenger ekstrelerinin fenolik bileşiklerinin tayin sonuçları}

Fenolik bileşiklerdeki hidroksillerin sayısı artıkça, buna parale olarak anti oksidatif etkisi de artmaktadır. 5 farklı kenger bitkisinden alınan dikenli ve yenilebilir örneklerinin fenolik asit bileşiklerinin analizleri sonucunda, toplam otuz sekiz fenolik bileşiğin analizi yapılmış olup bunlardan yirmi sekiz tanesinin fenolik asit açısından hiçbir etki göstermediği, sadece on tanesinin etki gösterdiği, hatta bazılarının da kısmen etki gösterdiği tespit edilmiştir.(Tablo 3) Özellikle kuinik asit (4.572 mg.L' $\left.{ }^{1}-21.28 \mathrm{mg} . \mathrm{L}^{-1}\right)$ ve gallik asit $\left(0,284 \mathrm{mg} . \mathrm{L}^{-1}-2.182 \mathrm{mg} . \mathrm{L}^{-1}\right)$ açısından yaklaştığımızda yüksek, derişimleri dikkat, çekmektedir (Tablo 3). Ayrıca burada dikkat çeken bir diğer önemli nokta ise hem kuinik asit hemde gallik asit fenolik bileşiklerinin derişimlerini kıyasladığımızda her ikisinde de kenger bitkidinin dikenli kısımlarının derişimleri yenilebilir kısımların derişiminden yüksek olduğu tespit edilmiştir. Kenger, bitkisinin fenolik bişleşiklerinin analizleri ile ilgili literatürde çalışmaya rastlayamadığımız için kıyaslama yapamıyoruz. Bu çalışmamızda ise tespit edilen fenolik bileşiklerin değerlerinin birbirine yakın olduğu fenolik bileşik açısından genel olarak çok az etki gösterdiği, ve de fenolik bileşik analizlerinde Rutin, Hesperidin, Isoquercitrin içeriklerinin tespit edilebilir düzeyde olmadığı gözlemlenmiştir.Bu alanda yapılan bilimsel çalışmalarda kenger bitkilerinin fenolik bileşik içeriklerinin özellikle de Kuinik asit ve Fumarik asit bileşikleri açısından zengin bir besin ve protein kaynağı olduğu için fonksiyonel gida bileşeni olarak kullanılabileceğini ve bu alanda geniş kapsamlı çalışmaların yapılması gerektiği kanaatine varılmıştır.

\subsection{Kenger örneklerinin antioksidan aktivite sonuçları}

Kenger örneklerindeki antioksidan aktiviteleri üç farklı yöntem olan; $\mathrm{ABTS}^{+\bullet}$ Radikal Giderme, DPPH Serbest Radikal Giderme ve İndirgeme Gücü şeklinde analiz edilerek elde edilen değerler ortalama \pm standart sapma olarak Tablo 6'da ayrıntılı biçimde verilmiştir. Bu üç farklı yöntemi ayrı ayrı değerlendirilerek sonuçları aşağıdaki gibi yorumlanmıştır. 
Tablo 6. Kenger örnekleri ve standartların antioksidan aktivite değerleri

\begin{tabular}{|c|c|c|c|}
\hline $\begin{array}{l}\text { Kenger Örnekleri } \\
\text { ve Standartlar }\end{array}$ & 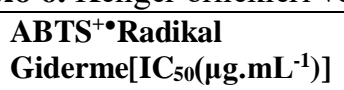 & $\begin{array}{l}\text { DPPH }^{\bullet} \text { Radikal Giderme } \\
{\left[\mathrm{IC}_{50}\left(\mu \mathrm{g} . \mathrm{mL}^{-1}\right)\right]}\end{array}$ & $\begin{array}{c}\text { İndirgeme Gücü } \\
\left(\mu \mathrm{mol} \text { TE.mL }{ }^{-1} \text { ekstre }\right)\end{array}$ \\
\hline Trolox & $7.98 \pm 0.22$ & $4.83 \pm 0.13$ & $4.83 \pm 0.13$ \\
\hline BHA & $5.23 \pm 0.10$ & $4.18 \pm 0.09$ & $6.51 \pm 0.04$ \\
\hline BHT & $7.03 \pm 0.19$ & $11.13 \pm 0.11$ & $5.24 \pm 0.08$ \\
\hline $1 Y$ & $274.31 \pm 4.02$ & $33.92 \pm 0.21$ & $0.27 \pm 0.005$ \\
\hline $2 Y$ & $480.60 \pm 4.46$ & $33.41 \pm 0.52$ & $0.18 \pm 0.003$ \\
\hline $3 Y$ & $629.97 \pm 9.37$ & $29.18 \pm 0.36$ & $0.12 \pm 0.001$ \\
\hline $4 Y$ & $389.21 \pm 2.36$ & $29.89 \pm 022$ & $0.20 \pm 0.002$ \\
\hline $5 Y$ & $320.56 \pm 2.14$ & $40.27 \pm 0.34$ & $0.24 \pm 0.003$ \\
\hline 1D & $410.23 \pm 4.97$ & $39.47 \pm 0.38$ & $0.16 \pm 0.002$ \\
\hline 2D & $526.15 \pm 4.47$ & $33.87 \pm 0.41$ & $0.22 \pm 0.003$ \\
\hline 3D & $590.15 \pm 5.36$ & $34.25 \pm 0.26$ & $0.27 \pm 0.001$ \\
\hline $4 \mathrm{D}$ & $562.14 \pm 4.96$ & $39.36 \pm 0.19$ & $0.21 \pm 0.001$ \\
\hline 5D & $602.36 \pm 6.08$ & $32.14 \pm 0.33$ & $0.18 \pm 0.002$ \\
\hline
\end{tabular}

\subsection{1. $\mathrm{ABTS}^{+}$radikal giderme sonuçları}

ABTS radikal giderme yönteminde ilk olarak mavi/yeşil renkte $\mathrm{ABTS}^{+\bullet}$ radikal katyonu oluşturulur. Antioksidan bileşiğin ilavesi ile bileşikten $\mathrm{ABTS}^{+\cdot}$ radikal katyonuna doğru elektron geçişi sağlanarak renk açılımı gerçekleşir. Antioksidan maddenin gücü nispetinde renk açılımı giderek artar. UV spektrofotometresi ile 734 nm'de yapılan ölçümler neticesinde elde edilen veriler Şekil 1'de grafik halinde gösterilmiştir. Burada absorbans değerleri ile antioksidan kuvveti arasında ters orantılı bir ilişki mevcuttur. Bu bilgiler ışığında (Şekil 1), grafiğini şöylece yorumlayabiliriz. $\mathrm{ABTS}^{+}$radikal giderme sonuçlarına baktığımızda örneklerin metanol ekstraktlarının standartlara kıyasla etkili bir $\mathrm{ABTS}^{+}$radikal katyon giderme aktivitesi göstermediği gözlemlenmiştir. Ekstrakların genel olarak yüksek dercede aktivite gösterdiği grafik üzerinde açık biçimde görülmektedir (Şekil 1). Özellikle kenger bitkisinin yenilebilir kısımları dikenli kısımlarına göre daha fazla aktivite gösterdiği tespit edilmiştir. Ayrıca dikenli kısımların radikal katyon giderme aktivitesi yenilebilir kısma nazaran daha istikrarlı(stabil) olduğu standart sapmasının daha az olduğu gözlemlenmiştir. Antioksidan etkileri çalışılan 10 tane kenger örneğini kendi aralarında karşılaştırdığımızda $\mathrm{ABTS}^{+\bullet}$ radikal giderme aktivitesi en yüksek olan bileşik $1 \mathrm{YK}$ ve $5 \mathrm{YK}$, en düşük olan ise $3 \mathrm{YK}$ örneğidir. Standartlar ile örnekleri karşılaştırdığımızda $\mathrm{ABTS}^{+\bullet}$ radikal giderme aktivite siralaması $\mathrm{BHA}>\mathrm{BHT}>$ Trolox $>1 \mathrm{Y}>5 \mathrm{Y}>3 \mathrm{Y}>4 \mathrm{Y}>1 \mathrm{D}>2 \mathrm{Y}>$ $4 \mathrm{D}>2 \mathrm{D}>3 \mathrm{D}>5 \mathrm{D}>3 \mathrm{Y}$ şeklinde olduğu anlaşılmıştır.

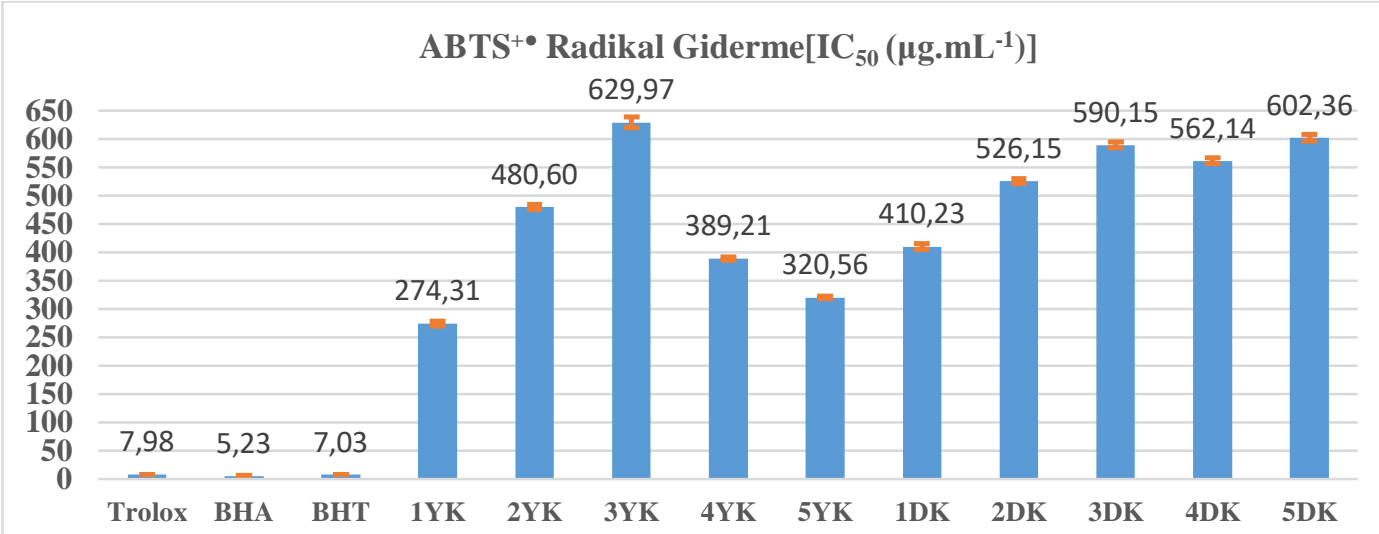

Şekil 1. Trolox, BHT, BHA standartları ile kenger örneklerinin ABTS radikal giderme aktiviteleri

\subsubsection{DPPH` serbest radikal giderme sonuçları}

Metanol ekstraktlarının standartlarla kıyaslandığında, daha düşük seviyede DPPH radikal giderme aktivitesi göstermiştir. Kenger örneklerin DPPH radikal giderme aktivitesi bakımından oldukça uyumlu ve dengeli bir aktiviteye sahip olduğu tespit edilmiştir. Burada da dikenli kısımların, yenilebilir kısımlara nispeten biraz daha fazla aktivite gösterdiği gözlemlenmiştir (Şekil 2). DPPH• serbest radikal 
varlığı ortamın rengini koyu menekşeye çevirir. Antioksidan ilave edildiğinde ise antioksidan'dan $\mathrm{DPPH} \bullet$ serbest radikaline doğru elektron geçişi olur. Antioksidanın gücü nispetinde elektron geçişi ile koyu menekşe olan renk de kaybolmaya başlar. 517 nm'de UV spektrofotometresi ile yapılan ölçümler neticesinde, okunan absorbans değeri ile antioksidan gücü arasında ters orantılı bir değişim gözlemlenmiş̧tir [31]. Elde edilen bu bilgiler ışığında 10 tane kenger örneğinin serbest radikal giderme aktiviteleri arasında aşağıdaki gibi bir ilişki ve sıralama elde edilmiştir. Standartlar ile kıyaslandığında antioksidan aktivite gücü BHA $>$ Trolox $>$ BHT $>1 \mathrm{Y}>5 \mathrm{Y}>4 \mathrm{Y}>1 \mathrm{D}>4 \mathrm{D}>4 \mathrm{Y}>2 \mathrm{D}>3 \mathrm{D}>5 \mathrm{D}>3 \mathrm{Y}$ şeklinde olduğu anlaşılmıştır.

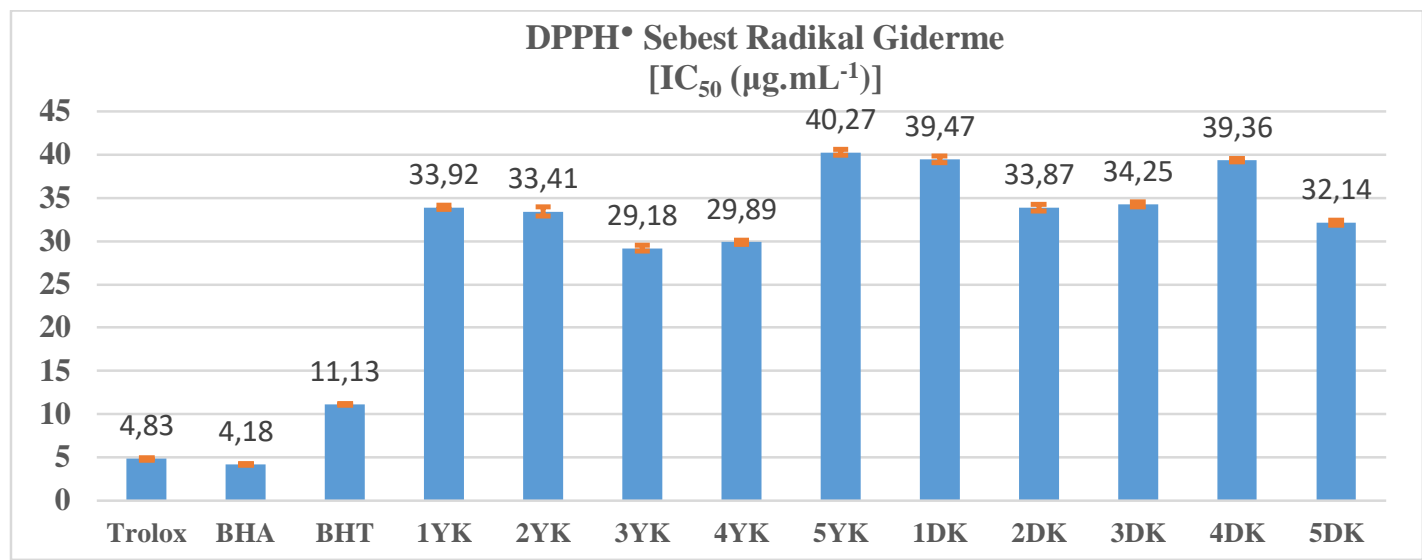

Şekil 2. Trolox, BHT, BHA standartları ile kenger örneklerinin DPPH serbest radikal giderme aktiviteleri

\subsection{3. İndirgeme gücü sonuçları}

Kenger örneklerinin metanol ekstraklarının indirgeme gücü aktivitelerinin standartlara göre oldukça düşük seviyede olduğu tespit edilmiştir. Ayrıca, kenger örneklerinin dikenli kısımlarının indirgeme gücü aktiviteleri yenilebilir kısımların indirgeme gücü aktivitelerinden daha yüksek olduğu gözlemlenmiştir (Şekil 3). İndirgenme gücü yönteminde $\mathrm{K}_{3}\left[\mathrm{Fe}(\mathrm{CN})_{6}\right]$ ile antioksidan bir sistem içinde karıştırıldığında $\mathrm{Fe}^{3+}$ iyonu $\mathrm{Fe}^{2+}$ iyonuna indirgenir ve $\mathrm{Fe}(\mathrm{CN})_{6}{ }^{4-}$ iyonu oluşur. $\mathrm{FeCl}_{3}$ ilavesi ile renkli $\mathrm{Fe}_{4}\left[\mathrm{Fe}(\mathrm{CN})_{6}\right]$ kompleksi oluşur. Dolayısıyla antioksidanın gücü artıkça renkli kompleksin derişimi de artar. UV spektrofotometresi ile $700 \mathrm{~nm}$ dalga boyunda yapılan ölçümler neticesinde kullanılan antioksidanın gücü ile ölçülen absorbans değeri arasında doğru orantılı bir artış gözlenmektedir. Elde edilen bu bilgiler 1şığıında Şekil 3'de yer alan standartlar ile 10 tane kenger örneğinin indirgenme gücü arasındaki ilişkinin BHA $>$ BHT $>$ Trolox $>3 \mathrm{D}>1 \mathrm{Y}>3 \mathrm{Y}>5 \mathrm{Y}>2 \mathrm{D}>4 \mathrm{D}>4 \mathrm{Y}>5 \mathrm{D}>1 \mathrm{D}>3 \mathrm{Y}$ şeklinde olduğu anlaşılmıştır.

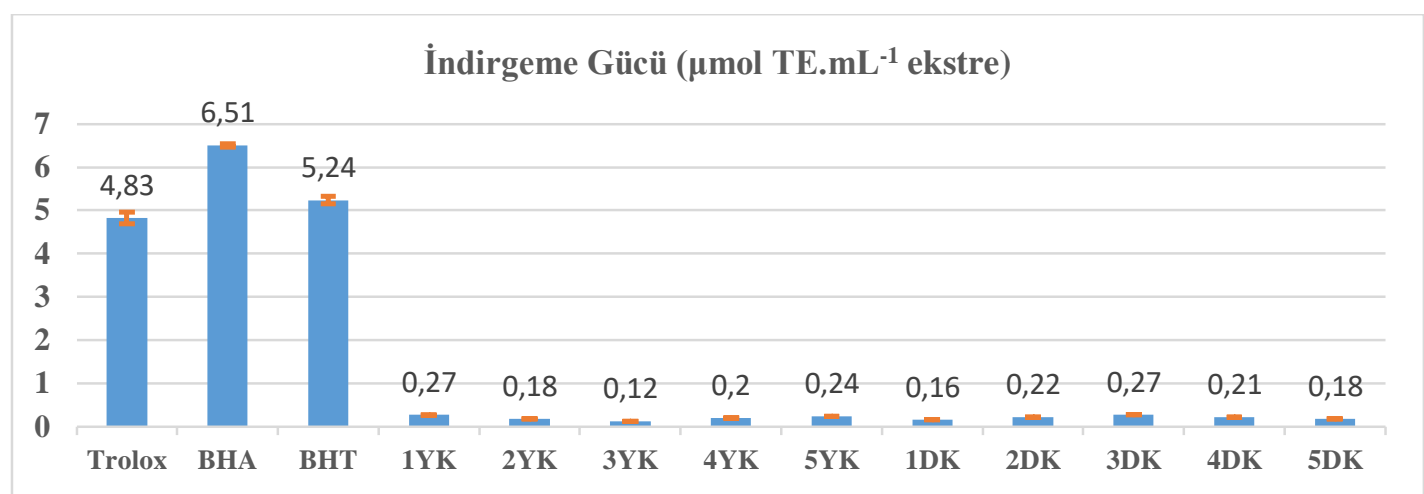

Şekil 3. Trolox, BHT, BHA standartları ile örneklerin indirgenme gücü aktiviteleri

\section{Sonuç ve Öneriler}

Dünyanın ve ülkemizin belirli bölgelerinde yaygın bir şekilde yetişen kenger bitkisi birçok kullanım ve tüketim alanına sahip olmakla birlikte, yetiştiği bölgelere göre de farklı tüketim biçimine haiz, otsu, dikenli ve tıbbi bir bitkidir. Besin, sağlık ve de şifa bulma niyetiyle bazı bölgelerde fazla miktarlarda 
tüketilip ya da kullanılmasının faydalarının yanısıra bazı endişeleri de beraberinde getirmiştir. Günümüzde teknolojinin ve sanayinin hılı biçimde gelişmesiyle, çevremiz gereğinden fazla kirlenmiş olup bu kirlilik önce toprak sonrasında bitki ve dolaysıyla da canlı ve insan hayatını önemli ölçüde tehdit ettiği bilinmektedir. Özellikle insanların tarımsal faaliyetlerinde gereğinden fazla kimyasal gübre, haşerelere karşı mücadele etmek için ise tarım ilaçlarının bilinçsizce kullanılması, topră̆ ciddi biçimde kirletmektedir. Bunun önüne geçmek, bitki ve meyve içeriğindeki besin elementlerinin ağır metal, fenolik asit ve antioksidan derişimler' ini koruyarak, verimlilik ve üretim kalitesinin arttırılması hedeflenmiştir. Tüm bitki, meyve ve sebze türlerinde besin ve toksik elementlerinin yanı sıra fenolik bileşik ve antioksidan aktivitesi son yıllarda oldukça dikkat çekmiş ve bu alanda birçok makale yayınlanmıştır. İnsanların sağlıklarını korumak ve sürdürebilmek adına organik besinlerin tüketmesi çok büyük önem arz etmektedir.Bilhassa ülkemizde üretimi ve tüketimi yaygın olan kenger bitkisinin insan sağlığı açısından önemli olan yüksek besleyici elementlere, fenolik bileşik içeriğine, yüksek antioksidan aktivitesine sahip olduğu tespit edildiğinden bu ve benzer özelliklere sahip bitki ve meyvelerin tüketilmesine ihtiyaç duyulduğu, ancak ölçülü ve kontrollü olarak tüketilmesi nin gerekli olduğu kanaatine varılmıştır.

\section{Teşekkür}

Bu çalışmanın laboratuvar kısmındaki katkılarından dolayı Hakan KIZILKAYA’ya Teşekkürlerimi sunuyorum.

\section{Yazarların Katkısı}

Makalede tüm katkı şahsıma aittir.

\section{Çıkar Çatışması Beyanı}

Yazarlar arasında herhangi bir çıkar çatışması bulunmamaktadır.

\section{Araştırma ve Yayın Etiği Beyanı}

Yapılan çalışmada araştırma ve yayın etiğine uyulmuştur.

\section{Kaynaklar}

[1] Çoruh N., Sağdıçoğlu Celep A.G., Özgökçe F., İşcan M. 2007. Antioxidant Capacities of GundeliaTournefortii L. Extracts and Inhibition on Glutathione-S-Transferase Activity. Food Chemistry, 100: 1249-1253.

[2] Demir A. 2013. Sürdürülebilir Gelişmede Yükselen Değer; Biyolojik ÇeşitlilikAçısındanTür kiye Değerlendirilmesi. İstanbul Ticaret Üniversitesi Fen Bilimleri Dergisi, 12 (24): 67-74.

[3] Asadi-Samani M.M, Rafieian-Kopaei ant N, Azimi. 2013. Gundelia: A Systematic Review of Medicinal and Molecular Perspective. Pakistan Journal of Biological Sciences, 16 (21): 1238-1247.

[4] Günal N. 2001. Türkiye'de Yöresel Olarak Sakız Elde Edilen Bitkiler. Türk Coğrafya Dergisi, 36: $17-30$

[5] Akan H., Korkut M.M., Balos M.M. 2008. Arat Dağı ve Çevresinde (Birecik, Şanlıurfa) Etnobotanik Bir Araştırma. Fırat Üniversitesi Fen Bilimleri ve Mühendislik Fakültesi Dergisi, 20 (1): 67-81.

[6] Polat B. 2012. Kayseri ve Çevresinde Yetişen Bazı Yabani Meyvelerin Biyoaktif Özelliklerinin Araştırılması, Erciyes Üniversitesi Fen Bilimleri Enstitüsü Yüksek Lisans Tezi, (Basılmış).

[7] Cakmakci S., Dagdemir E. 2013. A preliminary study on functionality of Gundelia tournefortii L. as a new stabiliser in ice cream production. International Journal of Dairy Technology, 66 (3): 431436.

[8] Haghi G., Hatami A., Arshi R. 2011. Distribution of Caffeic Acid Derivatives in Gundelia tournefortii L. Food Chemistry, 124: 1029-1035. 
[9] Tabibian M., Nasri S., Kerishchi P., Amin G. 2013. The Effect of Gundelia tournefortii HydroAlcoholic Extracts on Sperm Motility and Testosterone Serum Concentration in Mice. Zahedan Journal of Research in Medical Sciences, 15 (8): 18-21.

[10] Konak M., Ateş M., Şahan Y. 2017. Yenilebilir Yabani Bitki Gundelia tournefortii'nin Antioksidan Özelliklerinin Belirlenmesi. Uludağ Üniversitesi Ziraat Fakültesi Dergisi, 31 (2): 101-108.

[11] Hajizadeh-Sharafabada F., Alizadeh M., Mohammadzadeh M.H.S., Alizadeh-Saltehd S., Kheirouri S. 2016. Effect of Gundelia tournefortii L. Extracts on Lipid Profile ant TAC in Patients with Coronary Artery Disease: A double-Blind Randomized Placebo-Controlled Clinical Trial. Journal of Herbal Medicine, 6: 59- 66.

[12] Vermeer W., Nicholson R. 2006. Phenolic compound Biochemistry. Springer, 12: 1-276.

[13] Nizamlıoğlu N.M., Nas S. 2010. Meyve ve Sebzelerde Bulunan Fenolik Bileşikler; Yapıları ve Önemleri. Gıda Teknolojileri Elektronik Dergisi, 5 (1): 20-35.

[14] Dykes L., Rooney L.W. 2007. Phenolic Compounds in Cereal Grains and Their Health Benefits. Cereal Foods World, 52: 105-111.

[15] Polat R., Çakılcığlu U., Ertuğ F., Satıl F. 2012. An Evaluation of Ethnobotanical Studies in Eastern Anatolia. Biological Diversity and Conservation, 5 (2):23-40.

[16] Manach C., Scalbert A., Morand C., Remesy C., Jimenez L. 2004. Polyphenols: Food Sources and Bioavailability. American Journal of Clinical Nutrition, 79: 727-747.

[17] McDougall G.J., Dobson P., Smith P., Blake A., Stewart D. 2005. Assessing Potential Bioavailability of Raspberry Anthocyanins Using an in Vitro Digestion System. Journal of Agricultural and Food Chemistry, 53: 5896-5904.

[18] Etcheverry P., Grusak M.A., Fleige L.E. 2012. Application of in-vitro Bioaccessibility and Bioavailability Methods for Calcium, Carotenoids, Folate, Iron, Magnesium, Polyphenols, Zinc, and Vitamins B6, B12, D, and E. Frontiers in Physiology, 3 (317): 1-22.

[19] Bouayed J., Deußer H., Hoffmann L., Bohn T., 2012. Bioaccessible ant Dialysable Polyphenols in Selected Apple Varieties Following In Vitro Digestion vs. Their Native Patterns. Food Chemistry, 131: 1466-1472.

[20] Oghbaei M., Prakash J. 2013. Effects of Processing and Digestive Enzymes on Retention, Bioaccessibility and Antioxidant Activity of Bioactive Components in Food Mixes Based on Legumes and Green Leaves. Food Bioscience, 4: 21-30.

[21] Helal A., Tagliazucchia D., Verzellonia E., Conte A. 2014. Bioaccessibility of Polyphenols ant Cinnamaldehyde in Cinnamon Beverages Subjected to İn Vitro Gastro-Pancreatic Digestion. Journal of Functional Foods, 7: 506-516.

[22] Kilıçel F., Dağ B. 2006. The Relationship Between Some Heavy Metal Concentrations In Soils Leaves And Fruits Of Starring Delicious (Malus communis Lam.) In Van, Turkey. Reviews in Analytical Chemistry, 25 (4): 271-283.

[23] Türkdoğan M.K., Kilicel F., Kara K., Tuncer İ., Uygan İ. 2002. Heavy metals in soil, vegetables, and fruits in the endemic upper gastrointestinal cancer region of Turkey. Environmental Toxicology and Pharmacology, 13: 175-179.

[24] Bouhlali E.D.T., Alem C., Ennassir J., Benlyas M., Mbark A.N., Zegzouti Y.F. 2017. Phytochemical Compositions ant Antioxidant Capacity of Three Date (Phoenix dactylifera L.) Seeds Varieties Grown in the southeast Morocco, Journal of the Saudi Society of Agricultural Sciences, 16: 350357.

[25] Yılmaz M.A. 2015. Bazı Achıllea L. Türlerinin LC-MS-It/Tof ve LC-MS/MS İle Metabolik Profillerinin Çıkarılması ve Biyolojik Aktivitelerinin Belirlenmesi. Doktora Tezi, Dicle Üniversitesi Fen Bilimleri Enstitüsü, Diyarbakır.

[26] Re R., Pellegrini N., Proteggente A., Pannala A., Yang M., Rice-Evans C. 1999, Antioxidant Activity Applying an improved ABTS Radical Cation Decolorization Assay. Free Radical Biology and Medicine, 26: 1231-1237.

[27] Kızılkaya H., Dağ B., Aral T., Genç N., Erenler R. 2020. Synthesis, characterization, and antioxidant activity of heterocyclic Schiff bases. Journal of Chinese Chemical Society, 67: 1696-1701.

[28] Oyaizu M. 1986. Studies on products of browning reactions: antioxidative activities of products of browning reaction prepared from glucosamine. Jpn J Nutr, 103: 413-419.

[29] Anonim 2014. 2003.Toprak Kirliliğinin Kontrolü Yönetmeliği Resmi Gazete, Ankara, 2872: 1-137. 
[30] Dă̆ B., Kılıçel F. 2011. Determination of Cu Contamination in Some Spring and Mineral Waters Around Van by AAS after Enrichment of Activated Carbon. Joumal of Animal and Veterinary Advances, 5: 656-658

[31] Dağ B., Tarakçı Z., Demirkol M. 2016. Effect of Some total phenolic, antioxidants, physicochemical properties, mineral and heavy metal content of apricots drying types. Yaşam Bilimleri Dergisi, 6 (2) 238-249.

[32] Kızılkaya H. 2019. 4-Aminoantipirin Türevi Heterohalkalı Schıff Bazlarının Sentezi, Karekterizasyonu ve Antioksidan Aktiviteleri. Yüksek Lisans Tezi, Batman Üniversitesi Fen Bilimleri Enstitüsü, Batman. 